Journal of Tourism Theory and Research

Online, http://dergipark.gov.tr/jttr

Volume: 1(2), 2015

\title{
Applicability of cooperative learning model in gastronomy education
}

\author{
Mehmet Sarığlan ${ }^{1}$, Gülhan Cevizkaya ${ }^{2}$
}

\begin{abstract}
The purpose of the study is to reveal of "Cooperative learning model's applicability which is one of the vital models of gastronomy. Learning model that is based on cooperativisim, have importance for students in terms of being successful in their group Works at gastronomy education. This study divides into two parts, one is "literature" and other is "model proposal". At scanning of "literature" is going to be focused on cooperative learning model gastronomy education's description. In the second part, model offer is presented as cooperative learning model gastronomy can be applied. In this model offer, a course of action has been uncovered in order to develop gastronomy education and apply to cooperative learning model.
\end{abstract}

Keywords: Education of gastronomy, Education, Cooperative learning model

To cite this article: Sarığlan, M., Cevizkaya, G. (2015). Applicability of cooperative learning model in gastronomy education. Journal of Tourism Theory and Research, 1(2), 72-75. DOI: 10.24288/jttr.202824

\footnotetext{
${ }^{1}$ Asst. Prof. Dr., Balıkesir University, Tourism Faculty Balıkesir, TURKEY, mehmets@balikesir.edu.tr

${ }^{2}$ Research Asst., Balıkesir University, Tourism Faculty Balıkesir, TURKEY, gulhancevizkaya@gmail.com
} 


\section{Introduction}

In every step of life, to be healthy in terms of mental and physical ways and provide its continuation is possible with adequate and balanced nutrition and nourishment production. The Ology which deals with this work is called as Gastronomy (Santich, 2004; Harrington and Ottenbacher, 2010). According to The Maslow Needs Hierarchy; the need of catering is remarked as an indispensable need for individuals, To be able to provide those conditions are possible with the advancement in the education system , In our day, the mentality of education, it gives liability to a teacher deducting the most proper teaching method and carry it out so as to gain an effective teaching process, As one of the most important learning models in our day, Cooperative learning model provides more fruitful and effective chance to students (Hossain and Tarmizi, 2013; Sarığlan, 2012; Jalilifar, 2010).

\section{Cooperative learning model in gastronomy education}

The primary aim of people is to be fertile and productive. Individuals should be healthy in mental, social and physical ways and also eat sensibly, Gastronomy Education in countries education system be quantitative and qualitative (Ruetzler ve Taylor, 2009). Especially Turkish cuisine is one of the most essential cuisines in the World when its variety and ranges are considered (Sarığlan, 2012). But Turkey is quite backward in gastronomy education as quantitative and qualitative (Hegarty, 2011 and Stitt, 1996). In accordance with its value in Turkish Economy, Gastronomy Industry has not reached the point that we wish yet. (Sarığlan, 2012). Gastronomy Education divides into two parts in Turkey, one is secondary education and other is higher education. In secondary education, it takes part at food and beverage and kitchen departments in Anatolian Hotel Management and Tourism Vocational High School and Girl's Vocational School. Students that get education in Secondary School are about 4600 in 80 school. (Ministry of National Education Commercial and Tourism General Directorate). Gastronomy Education for higher education status is performed as undergraduate and associate degree. So we can figure out that the quality of gastronomy education is quite low in Turkey by estimating those values. On the other hand, it is also hard to say that gastronomy education is enough for its qualitative way. It is concluded that there necessity an applicable strategy plan in Gastronomy education to be able to its Advancement. Cooperative learning model has been described and called with very different kind of names. Cooperative learning model is called in English as 'cooperative learning' and in Turkish it is translated as 'işbirlikli öğrenme' by Açıkgöz ( 1991) Cooperative learning model is a kind of learning approach for students by composing mixed groups in classes and helping each other with a common purpose and also targeting an academic success among themselves (Açıkgöz, 2002).According to Goodwin (1999) Cooperative Learning is a teaching method comprised by small nonhomogeneous students groups by aiming an common purpose and all the participants are in cooperation.

According to Doymuş et.al (2013) Cooperative learning is a learning approach by students composing some small nonhomogeneous groups both at classes and outside and aiming cooperative study together and help themselves in an academically topic.Withing the frame of all those descriptions, principles of cooperative learning can be summarized like this (Herrmann, K.J., 2013; Drakeford, 2012; Goyak 2009; Adeyemi, 2008; Abu and Flower, 1997)

\subsection{Positive dependency}

It is the most essential principle of Cooperative Learning, without it, there no happens any Cooperative learning, it explains for each member of group to fulfill their responsibilities. At the same time Students should be aware of the impact of collaboration and both for success and fail depends of their teamwork. There are few of strategy to compose positive dependency, one of them is material. A tool box can be composed from equipments in their kitchen .Positive dependeny can be created by changing the kitchen equipment among groups and other positive dependency strategy are missions. Some varieties of mission may be considered for students in groups. Mission given to students don't only help them to focus on the topic but also help them to gain practical skills, improve themselves in a private branch and also help putting an information into practice. At the end of study, the mentality of the success came with cooperative work consolidates for students to be successful and provides them to act like this. Hence gastronomy students in the scope of 
cooperative learning, they work together in accordance with aiming the common purpose

\subsection{Individual responsibility}

In the traditional learning method, the successes of individuals is detected by the point they got from exams yet, In the cooperative learning model, the success is not solely with the points that individuals got from exams. Generally in group works can also be provided a success and responsibility is gained by student to study together and collaborative duties.

\subsection{Comprising group and group mind}

Cooperative learning groups usually are taken into consideration in terms of their prior success and founded by looking at these circumstances in a shape of nonhomogeneous. At the education of Gastronomy, Students may be divided into according to their private scopes such as pastry, grade manger (cold kitchen), hot kitchen. Therefore students are located into groups by viewing many conditions and more proper group formation is provided for cooperative learning techniques. Those stuffs occur the group mind without members awareness. So it is inevitable to be successful.

\subsection{The role of teacher}

In the process of this model, teacher have great responsibilities. In order to obtain an effective and fertile results from collaborative learning model, there has to be prepared proper environments to live social interaction among individuals. In the branch of Gastronomy, qualitative teachers and tutor must be trained. For instance, it can be described that the tutors and teachers in gastronomy branch didn't get any special education in gastronomy field. At this frame, the plans and organizations have to be raised. To be able to effective and fertile, cooperative learning studies, there has to be comprised an intense social interaction and proper environments should be set. Additionally, the students ought to take an accelerative and directive role for themselves.

\section{Material and method}

The purpose of this study, in gastronomy education, cooperative learning should be developed in a model offer. In this study, qualitative searching technique was used. Qualitative research technique was used .Qualitative research is a kind of search which is used some data like observation, meeting, and document analyze. Another research has mentality to compose a theory and also search the social concepts in the environment they belong to (Yıldırım et.al Şimşek, 2000) Physiology, sociology, anthropology and like education, it looks in behaviors of public. (Ergun 2005)In Education of Gastronomy, it has researched how much it has impact on teachers by viewing their backgrounds and capability and also its appliance on the students. At the end of researches, there is no any work on it. So to study on it will contribute to Gastronomy field.

\section{Applicability of cooperative learning model in gastronomy education}

The purpose of study is to improve a model offer for cooperative learning model. A this frame, in the gastronomy education, there has been improved a new kind of model offer. First step of application model offered is to compose crews. At first there has to be some advices about how and what sort of they can be developed the second step of model offer is the problem solve process of crews. At this stage, there are some offers to deal with their problems. The third and final process of model offer is to provide crew to research and develop possibility.

\section{Phase 1: Composing to Crews}

The first phase pf model is to compose crews. At this method, there homogeneous have to be preferred. The students who are homogeneous can only unify one mastership field. Every student should be aware other masterships too instead of his own mastership. He should teach information about his mastership and also he should learn their mastership too. So students can create group work

\section{Phase 2: Problem Solving Process}

At problem solving process, the crew composing the second stage of model one question can be given to student in group. It can be asked from students to find a way of solution for instance to prepare a different kind of menu may be asked. It is like a different serving, untested meal. Therefore, every student should perform and act together though they are in different fields. Students who can't deal with the question may participate into education seminars. In gastronomy field, by means of many seminar and 
participation to courses it can led to them to master at this field.

\section{Phase 3: Providing to search and improve}

The final phase of model is to provide crew improving and searching. After they finish the target wanted, crews can be seen in any different presentations. To improve and level up possibility of crew is to be given by lecturers and so students may develop some kinds of different solving ways by searching.

\section{Results}

In the search, it is deduced that gastronomy education is an important science branch in individuals' life. In the literature scanning, it is seen that there is a deficiency in gastronomy education. At this frame, to be able to develop of gastronomy education, cooperative learning model is offered which is one of the education programs.

The greatest advantage of model offered in study is its applicability function. The use of Model offered in study effectively is going to contribute to develop of education of gastronomy and also raise the value of successes of students.it is believed that this study is going to be a formation and example for the next ones.

\section{References}

Abu, R.B., Flower, J., (1997). The Effect of Cooperative Learning Methods on Achievement, Retention, and Attitudes of Home Economic Students in North Carolina, Journal of Vocational and Technical Education, 13 (2).

Açıkgöz, K. Ü. (2002). Aktif öğrenme. İzmir: Eğitim Dünyası Yayınları.

Açıkgöz, K. Ü. (1991). Cooperative, competitive and traditional activities in foreign language achievement and retention. Paper Presented at TESOL 25th Annual Convention and Exposition. New York: March 24-28.

Adeyemi, B.A. (2008). Effects of Cooperative Learnşng and Problem-Solving Strategies on Junior Secondary School Students Achievement in Social Studies, Electronic Journal of Research in Educational Psychology, 6 (3), 691-708.
Doymuş, K. Bayrakçeken, S. ve Doğan, A. (2013). İşbirlikli Ögrenme Modeli ve Uygulanması. Ankara: Pegem Akademi Yayınc1lik.

Drakeford, W. (2012). The Effesct of Cooperative Learning on the Classroom Participation of Students Placed at Risk for Societal Failure, Psychology Research, 2 (4), 239-246.

Ergün, M.(2005). Bilimsel araştırma yöntemleri, nitel araştırma http://www.egitim.aku.edu.tr/nitelarastirma.ppt\#256,1,

Goyak, A. (2009). The Effect Cooperative Learning Techniques on Perceived Classroom Enviroment and Critical Thinking Skills of Preservice Teachers, A Dissertaion, The Faculty of the School of Education Liberty University.

Harrington, R. \& Ottenbacher, M.C. (2010). Culinary Tourism-A Case Study of the Gastronomic Capital. Journal of Culinary Science \& Technology, 8 (1), 14-32.

Hegarty, J. A. (2011). Achieving Excellence by Means of Critical Reflection an Cultural Imagination in Culinary Arts and Gastronomy Education. Journal of Culinary Science \& Technology, 9, 2, 55-65.

Herrmann, K.J. (2013). The Impact of Cooperative Learning on Student Engagement: Result form an Intevention, Active Learning in Higher Education 14(3), 175-187.

Hossain, A., Tarmizi, A.R. (2013). Effect of Coorperative Learning on Students Achievement and Attitudes in Secondary Mathematics, Procedia-Social and Behavioral Sciences, 93 (1), 473-477.

Jalilifar, A. (2010). The Effect of Cooperative Learning Techniques on College Students Reading Comprehension, The Journal of International System, 38 (1). 96-108.

Milli Eğitim Bakanlığı Ticaret ve Turizm Eğitimi Genel Müdürlüğü, http://ttogm.meb.gov.tr Erişim Tarihi: 10.09.2015

Ruetzler, T. ve Taylor, J. (2009). Internet Sites of Current Interest to Culinarians and Culinary Teachers. Journal of Culinary Science \& Technology, 7,1, 34-36.

Santich, B. (2004). The study of gastronomy and its relevance to hospitality education and training. International Journal of Hospilaty Management, 23, 1524

Sarığlan, M. (2012). Türkiye'de Gastronomi Eğitiminin Mevcut Durumu ve Geliştirilmesine Yönelik Bir Model Önerisi. IV. Uluslararası Türkiye Eğitim Araștırmaları Kongresi: İstanbul, 141-145.

Yıldırım, A. ve Simsek, H. (2000). Sosyal Bilimlerde Nitel Araştırma Yöntemleri. (2. baskı) Ankara: Seçkin Yayınevi 